GRASAS Y ACEITES 68 (1)

January-March 2017, e183

ISSN-L: 0017-3495

doi: http://dx.doi.org/10.3989/gya.0810162

\title{
Antioxidant activity and sensory analysis of murtilla (Ugni molinae Turcz.) fruit extracts in an oil model system
}

\author{
T.R. Augusto-Obara ${ }^{\mathrm{a}}$, F. Pirce ${ }^{\mathrm{b}}$, E. Scheuermann ${ }^{\mathrm{b}}$, M.H.F. Spoto ${ }^{\mathrm{a}}$ and T.M.F.S. Vieira ${ }^{\mathrm{a}, \mathbb{}}$ \\ ${ }^{a}$ Department of Agroindustry, Food and Nutrition, College of Agriculture "Luiz de Queiroz", University of São Paulo, \\ Av. Pádua Dias 11, 13418-900, Brazil \\ ${ }^{\mathrm{b}}$ Chemical Engineering Department and Center of Food Biotechnology and Bioseparations (BIOREN), \\ Universidad de La Frontera, Av. Francisco Salazar 01145, Temuco, Chile \\ ${ }^{\square}$ Corresponding author: tvieira@usp.br
}

Submitted: 05 August 2016; Accepted: 03 January 2017

SUMMARY: An oil model system was used to analyze the antioxidant activity of Chilean fruit extracts and to determine their odor sensory effect. Hydroalcoholic extracts from wild and 14-4 genotype murtilla (Ugni molinae Turcz.) fruit were assessed by the Response Surface Methodology. The optimal conditions for producing high total phenolic-content extracts were $49.5 \%$ (v/v) ethanol at $30^{\circ} \mathrm{C}$, which yielded 18.39 and $26.14 \mathrm{mg}$ GAE $\cdot \mathrm{g}^{-1}$ dry matter, respectively. The optimized extracts were added to a lipid model system and evaluated via the Schaal Oven Test. After 96 hours, 150 and $200 \mathrm{mg} \cdot \mathrm{kg}^{-1}$ oil of the wild and 14-4 genotype extracts, respectively, showed an antioxidant capacity similar to TBHQ $\left(200 \mathrm{mg} \cdot \mathrm{kg}^{-1}\right.$ oil $)$ in terms of peroxide values and odor. Thus, murtilla fruit extracts are a natural source of antioxidants for protecting lipidic foods, such as soybean oil.

KEYWORDS: Antioxidant activity; Murtilla; Oil model system; Oil organoleptic characteristic; Response Surface Methodology; Total polyphenol content

RESUMEN: Actividad antioxidante y evaluación sensorial de extractos de frutos de murtilla (Ugni molinae Turcz.) en un sistema modelo aceitoso. Se analizó la actividad antioxidante de extractos de una fruta chilena en un sistema modelo aceitoso y se determinó el efecto sobre las características organolépticas. Se utilizaron extractos hidroalcohólicos de frutos de murtilla (Ugni molinae Turcz.) silvestre y del genotipo 14-4, y se aplicó la Metodología de Superficie de Respuesta. Las condiciones óptimas para obtener extractos con altos contenidos de fenoles totales fueron $49,5 \%$ (v/v) de etanol a $30^{\circ} \mathrm{C}$, lo que produjo 18,39 y 26,14 $\mathrm{mg} \mathrm{AGE} \mathrm{g}^{-1}$ materia seca, respectivamente. Los extractos optimizados se añadieron a un sistema modelo aceitoso y se evaluaron a través de una prueba de estabilidad en horno Schaal. Después de 96 horas, los extractos de frutos silvestre (150 mg $\mathrm{kg}^{-1}$ aceite) y genotipo 14-4 (200 mg $\mathrm{kg}^{-1}$ aceite) mostraron una capacidad antioxidante similar al TBHQ (200 mg $\mathrm{kg}^{-1}$ aceite) en términos de índice de peróxido y respecto a las características organolépticas. Se concluye que los extractos de frutos de murtilla son una fuente natural de antioxidantes para la protección de los alimentos lipídicos, tales como el aceite de soja.

PALABRAS CLAVE: Actividad antioxidante; Características organolépticas del aceite; Contenido de polifenoles totales; Metodología de Superficie de Respuesta; Murtilla; Sistema modelo aceitoso

ORCID ID: Augusto-Obara TR http://orcid.org/0000-0001-9272-9170, Pirce F http://orcid.org/0000-0003-1668-2934, Scheuermann E http://orcid.org/0000-0002-6782-662X, Spoto MHF http://orcid.org/0000-0001-9219-6343, Vieira TMFS http://orcid.org/0000-0002-2485-0240

Citation/Cómo citar este artículo: Augusto-Obara TR, Pirce F, Scheuermann E, Spoto MHF, Vieira TMFS. 2017. Antioxidant activity and sensory analysis of murtilla (Ugni molinae Turcz.) fruit extracts in an oil model system. Grasas Aceites 68, e183. http://dx.doi.org/10.3989/gya.0810162

Copyright: (C) 2017 CSIC. This is an open-access article distributed under the terms of the Creative Commons Attribution (CC-by) Spain 3.0 License. 


\section{INTRODUCTION}

Lipid oxidation is the most important cause of food deterioration and leads to changes in flavor and nutritional compounds that reduce palatability. For the food industry, these changes cause enormous commercial damages, which justifies the continuous search for new technologies to help improve food product shelf life, such as changing package constituents, reducing oxygen contact with food, increasing food production care and adding antioxidant compounds (Zhang et al., 2013; Alves et al., 2015; Cichello, 2015). Antioxidants from natural or synthetic sources are capable of retarding or reducing the oxidation reaction in lipid compounds (Shahidi, 1997). However, the use of synthetic antioxidants in foods may be restricted or prohibited because high quantities of lipid compounds may be detrimental to human health. Therefore, many researchers have focused on obtaining antioxidants from natural sources and assessed the activity of these antioxidants against free radicals and evaluated their potential uses in foods (Karpińska et al., 2001; Scheuermann et al., 2002; Yanishlieva et al., 2006; Brewer, 2011; Shah et al., 2014; Shi et al., 2014).

Among the most studied natural sources of antioxidants are fruits, herbs and spices, which possess phenolic compounds capable of acting as antimicrobials, anti-allergens, anti-teratogens, antithrombotics, cardio-protectors and vasodilators (Zhang et al., 2011; Bektas et al., 2012; Simin et al., 2013; Del Monte et al., 2015; Claro et al., 2015).

Fresh and dried murtilla (Ugni molinae Turcz.) fruit, which is a Chilean berry, exhibit antioxidant activity via phenolic compounds (Alfaro et al., 2013; Augusto et al., 2014; Suwalsky and Avello, 2014; Rodríguez et al., 2014; Junqueira-Gonçalves et al., 2015; Jofré et al., 2016). For being a seasonal fruit, the drying process is considered an adequate technique for its preservation which saves the antioxidant properties provided by its polyphenolic components (Alfaro et al., 2014).

In this study, experiments using the Response Surface Methodology were performed to analyze the effects of different solvents and temperatures on the extraction of the phenolic content of dehydrated murtilla (Ugni molinae Turcz.) fruit. The antioxidant activity of the extracts obtained under the optimized conditions was then evaluated in refined soybean oil as a model system, and the effect of the extracts on the organoleptic characteristics of the oil were determined by a sensory evaluation.

\section{MATERIALS AND METHODS}

Folin-Ciocalteu phenol reagent was purchased from Sigma-Aldrich Chemical Co. (St. Louis, MO, USA). All other chemicals and solvents were purchased from Fisher Scientific (Nepean, Canada) and were of ACS grade or better. Refined soybean oil without synthetic antioxidants was donated by Cargill (Mairinque, São Paulo, Brazil).

\subsection{Plant material and extract preparation}

Murtilla fruits (Ugni molinae Turcz.) were obtained from wild and cultivated plants. The wild fruits were obtained from native vegetation in Puerto Saavedra $\left(38^{\circ}, 45^{\prime} \mathrm{S}, 73^{\circ} 21^{\prime} \mathrm{W}\right)$, La Araucanía Region, Chile. The cultivated fruits (14-4 genotype) were grown in the germ plasm bank at the experimental station of Instituto de Investigaciones Agropecuarias (INIA) at Puerto Saavedra. The wild and cultivated fruits were harvested on April 18, 2011 and dried on April 19, 2011 using an industrial drying cabinet $(1.8 \mathrm{~m}$ long, $2.2 \mathrm{~m}$ high, $3.5 \mathrm{~m}$ deep) at a constant temperature of $70{ }^{\circ} \mathrm{C}$ for 6 hours until a final moisture content of $5.4 \%$ was reached, according to Alfaro et al. (2014). The fruits were vacuum packed and protected from light and oxygen. The hydro-alcoholic extracts were prepared according to the method described by Ribeiro et al. (2008) with certain modifications. Different concentrations of ethanol:water and different temperatures were used throughout the experiments (see Table 1 for the conditions) in an attempt to improve the extraction of polyphenols. The dehydrated fruit was ground, and $1.0 \mathrm{~g}$ of the samples was placed in a $250 \mathrm{~mL}$ Erlenmeyer with $30 \mathrm{~mL}$ of solvent $(\mathrm{v} / \mathrm{v}$, ethanol/water) and heated to a specific temperature (see Table 1), which was maintained for 50 minutes under agitation in a water bath (Model NI 1322220, Nova Instrumentos, Brazil). The extracts were then centrifuged at $2057 \mathrm{~g}$ for 15 minutes, filtered using Whatman $\mathrm{N}^{\circ} 2$ filter paper, and stored under refrigeration at $7{ }^{\circ} \mathrm{C}$ in amber flasks until analysis.

\subsection{Experimental design, murtilla fruit extraction and total phenolic content}

The Response Surface Methodology and a multiple regression analysis were performed to determine the effects of the solvent ratio (ethanol:water) and temperature on the total phenolic content (dependent variable) in the murtilla fruit extracts to identify the best conditions for obtaining high antioxidant activity. Adjustments were performed to generate a second order mathematical model that included linear and quadratic terms as well as their interactions. To estimate the experimental error, four assays with coded values related to zero levels, which represented the central point, were performed. To complete the design, trials referencing the axial points positioned at a distance $\alpha\left(\alpha=2^{n / 4}\right)$ from the central point were conducted. At the end of the design, twelve trials had been performed. The experimental design is shown in Table 1. 
TABLE 1. Coded levels and actual values of the independent variables used to optimize the extraction conditions of wild and 14-4 genotype (14-4) murtilla fruits. Their effect on the total phenolic content (TPC) was used as a dependent variable

\begin{tabular}{|c|c|c|c|c|c|c|}
\hline \multirow[b]{2}{*}{ Assay } & \multicolumn{2}{|c|}{ Coded levels } & \multicolumn{2}{|c|}{ Actual values } & \multicolumn{2}{|c|}{ TPC (mg GAE $\cdot g^{-1}$ dry matter)* } \\
\hline & Ethanol & Temperature & Ethanol (\%) & Temperature $\left({ }^{\circ} \mathrm{C}\right)$ & Wild* & $14-4 *$ \\
\hline 1 & -1 & -1 & 14.4 & 34.4 & 14.2 & 20.4 \\
\hline 2 & 1 & -1 & 84.6 & 34.4 & 9.9 & 8.8 \\
\hline 3 & -1 & 1 & 14.4 & 55.6 & 14.6 & 22.6 \\
\hline 4 & 1 & 1 & 84.6 & 55.6 & 11.6 & 17.6 \\
\hline 5 & -1.41 & 0 & 0 & 45 & 11.3 & 14.6 \\
\hline 6 & 1.41 & 0 & 99 & 45 & 7.3 & 5.5 \\
\hline 7 & 0 & -1.41 & 49.5 & 30 & 18.3 & 26.1 \\
\hline 8 & 0 & 1.41 & 49.5 & 60 & 18.8 & 27.9 \\
\hline 9 & 0 & 0 & 49.5 & 45 & 17.5 & 25.2 \\
\hline 10 & 0 & 0 & 49.5 & 45 & 17.7 & 23.6 \\
\hline 11 & 0 & 0 & 49.5 & 45 & 18.0 & 27.2 \\
\hline 12 & 0 & 0 & 49.5 & 45 & 19.4 & 27.7 \\
\hline
\end{tabular}

*Values represent the mean of three replicates expressed as mg gallic acid equivalent (GAE) of dry matter (g).

The mathematical model was evaluated based on the coefficient of determination $\left(\mathrm{R}^{2}\right)$ and $\mathrm{F}$ test, which were determined by a variance analysis using Statistica 11 software (Stat Soft, 2013). The general equation is $\mathrm{Y}=\mathrm{b}_{0}+\mathrm{b}_{1} \mathrm{x}_{1}+\mathrm{b}_{2} \mathrm{x}_{2}+\mathrm{b}_{11} \mathrm{x}_{1}{ }^{2}+\mathrm{b}_{2} \mathrm{x}_{2}{ }^{2}+$ $b_{12} x_{1} x_{2}$, where $Y$ is the dependent variable, $x_{1}$ and $x_{2}$ are the coded levels of the explanatory variables, $\mathrm{b}_{0}$ is the central point and b' is the estimated coefficient from the minimum square method. The total phenolic content of the extracts was the dependent variable in the experimental design. The measurements were determined in triplicate according to the method described by Singleton et al. (1999) using the FolinCiocalteu solution as a reagent and gallic acid as a standard. The hydroalcoholic extracts were diluted in ethanol at concentration of 1:10 (extract: ethanol, $\mathrm{v} / \mathrm{v})$. An aliquot of $0.5 \mathrm{~mL}$ of the diluted sample was transferred to a test tube, and $2.5 \mathrm{~mL}$ of the FolinCiocalteu reagent:water solution $(1: 10, \mathrm{v} / \mathrm{v})$ were added. The mixture was vortexed at room temperature in the dark, and after a 5 minute resting period, $2.0 \mathrm{~mL}$ of a sodium carbonate $4 \%(\mathrm{~m} / \mathrm{v})$ solution was added, and the mixture was agitated again and kept at rest for two hours at room temperature and protected from light. The absorbance was read at $740 \mathrm{~nm}$ using a UV-1203 spectrophotometer (Shimadzu Corporation, Japan). The results were calculated using the standard curve of gallic acid with known concentrations (2.5 to $\left.50 \mu \mathrm{g} \cdot \mathrm{mL}^{-1}\right)$, and the results were expressed in $\mathrm{mg}$ of gallic acid equivalent (GAE) of dry matter (g).

\subsection{Accelerated stability assessed via the Schaal Oven Test to measure the antioxidant activity against lipid oxidation}

Ten treatments were established to evaluate the antioxidant ability to prevent lipid oxidation via accelerated stability tests. These treatments included the addition of 50, 100, 150 and $200 \mathrm{mg}$ GAE kg. oil ${ }^{-1}$ of the wild and 14-4 genotype extracts of murtilla to soybean oil and $200 \mathrm{mg}$ of TBHQ $\mathrm{kg} \cdot \mathrm{oil}^{-1}$ to soybean oil. The control treatment consisted of refined soybean oil alone. The total phenolic contents (determined by the Folin-Ciocalteu method) were used to calculate the concentrations of the added extracts ( $\mu \mathrm{g} \mathrm{GAE} \cdot \mathrm{mL}^{-1}$ ).

For each trial, the samples were prepared in triplicate, binned in $50 \mathrm{~mL}$ beakers and randomly distributed in the oven. The established temperature was $63 \pm 2{ }^{\circ} \mathrm{C}$ and after 36, 72 and 96 hours, the samples were removed for peroxide and ultraviolet absorption analyses.

\subsection{Antioxidant activity measure by the peroxide value (PV) and ultraviolet absorption (UV)}

The peroxide value was determined according to the Cd 8b-90 method (American Oil Chemists' Society, 2009), and the results are expressed in meq $\mathrm{O}_{2} \cdot \mathrm{kg}^{-1}$ oil. The specific absorbance was determined according the $\mathrm{Ch}$ 5-91 method (American Oil Chemists' Society, 2009), and the results were expressed in $\mathrm{E}^{1 \%} \mathrm{~cm}$. The absorbance was read at $232 \mathrm{~nm}$ using a UV-1203 spectrophotometer (Shimadzu Corporation, Japan).

\subsection{Sensory analysis}

The discriminative test was conducted using an unstructured scale with 6 trained tasters to evaluate the odor (rancidity). For this test, $20 \mathrm{~mL}$ from each treatment were kept in black plastic cups labeled with three-digit numbers and randomly distributed in the oven at $43{ }^{\circ} \mathrm{C}$ (Institute of Food Technologists, 1981). The complete block design 
was applied, and the results were analyzed using the statistics discussed in section 2.6.

\subsection{Statistical analysis}

All evaluations were conducted in triplicate, and the results were expressed as the mean \pm standard deviation. The data were statistically analyzed via an analysis of variance (ANOVA) and Tukey's test $(\alpha=95 \%)$ using SAS (Statistical Analysis System, USA) software.

\section{RESULTS AND DISCUSSION}

\subsection{Effect of solvent and temperature on the total phenolic content}

The total phenolic contents of the murtilla fruit extracts using different extraction conditions are shown in Table 1. The estimated effects on the total phenolic content for each murtilla fruit extract (wild and 14-4 genotype) are shown in Table 2.

According to Table 2, the extraction process for both samples of murtilla were affected by the solvent because the linear and quadratic effects were statistically significant. However, the effects of increases in temperature, which promoted an increase in the total phenolic content of the extract were not statistically significant $(\mathrm{p}<0.05)$.

Despite the differences in the results for each trial, both murtilla fruit extracts (wild and 14-4 genotype) showed the same relationship between the total phenolic content and the solvent. After the effects analysis, terms that were not significant were eliminated, and second-order regression coefficients were obtained.
The second-order polynomial equation for the total phenolic content (TPC) for wild murtilla is:

$\mathrm{TPC}\left(\mathrm{mg} \mathrm{GAE} \cdot \mathrm{g}^{-1}\right.$ dry matter $)=18.09542-1.64877$ *\%Ethanol $-4.76455 * \%$ Ethanol $^{2}$

and the mathematical model for the 14-4 genotype murtilla is:

TPC $\left(\mathrm{mg} \mathrm{GAE} \cdot \mathrm{g}^{-1}\right.$ dry matter $)=26.165239-3.66933$ *\%Ethanol $-8.32753 * \%$ Ethanol $^{2}$

The analysis of variance (Tables 3 and 4) demonstrated that the proposed models were valid because the regressions were statistically significant. The $F$ test showed that the lack of fit was not statistically significant $(\mathrm{p}<0.05)$. The coefficients of determination $\left(\mathrm{R}^{2}\right)$ were higher than 0.90 . Thus, the ANOVA results indicated that the $F$ values calculated from the regressions of both models were three times higher than the $\mathrm{F}$ values that were tabulated. Therefore, the mathematical models were valid, and they can be used for predictive purposes.

The adjusted response surfaces of the mathematical models for murtilla fruit extracts from wild and 14-4 genotypes are shown in Figure 1. An ethanol concentration of $49.5 \%(\mathrm{v} / \mathrm{v}$, ethanol:water) under all temperatures provided a higher yield of total phenolic content (18.39 and $26.14 \mathrm{mg} \mathrm{GAE} \cdot \mathrm{g}^{-1}$ dry matter for the wild and 14-4 genotype murtilla). Thus, $49.5 \%$ ethanol (v/v, ethanol:water) was the optimal solvent concentration for the extraction of this substrate. Values over 50\% ethanol (v/v, ethanol:water) showed a reduced extraction efficiency.

Our results show that under the same solvent concentration, the total phenolic content of the 14-4 genotype murtilla fruit extract was significantly

TABLE 2. Estimated effects of the explanatory variables on the total phenolic content of the wild and 14-4 genotype murtilla fruit extracts

\begin{tabular}{|c|c|c|c|}
\hline & Effect & Standard deviation & $p$-value \\
\hline \multicolumn{4}{|l|}{ Wild } \\
\hline Mean & 18.1932 & 0.4326 & 0.0000 \\
\hline Ethanol (L) & -3.2975 & 0.6127 & 0.0126 \\
\hline Ethanol (Q) & -9.5775 & 0.6868 & 0.0008 \\
\hline Temperature (L) & 0.6942 & 0.6127 & 0.3396 \\
\hline Temperature (Q) & -0.2458 & 0.6868 & 0.7441 \\
\hline Ethanol (L) x Temperature (L) & 0.6862 & 0.8652 & 0.4856 \\
\hline \multicolumn{4}{|l|}{ 14-4 genotype } \\
\hline Mean & 25.9713 & 0.9553 & 0.0001 \\
\hline Ethanol (L) & -7.3387 & 1.3530 & 0.0123 \\
\hline Ethanol (Q) & -16.5590 & 1.5167 & 0.0016 \\
\hline Temperature (L) & 3.3676 & 1.3530 & 0.0886 \\
\hline Temperature (Q) & 0.4874 & 1.5167 & 0.7690 \\
\hline Ethanol (L) x Temperature (L) & 3.2805 & 1.9105 & 0.1845 \\
\hline
\end{tabular}

Bold terms: statistically significant at $95 \%$ confidence $(\mathrm{p}<0.05)$.

$\mathrm{L}=$ linear; $\mathrm{Q}=$ quadratic. 
TABLE 3. Analysis of variance (ANOVA) for the total phenolic content of the wild murtilla fruit extracts

\begin{tabular}{lcccc}
\hline Source & Sum of squares & df & Mean square & $\boldsymbol{F}$ value \\
\hline Model & 171.5866 & 2 & 85.79331 & 96.96129 \\
Residual & 7.9634 & 9 & 0.88482 & 1.273172 \\
Lack of fit & 5.7179 & 6 & 0.952977 & \\
Pure error & 2.2455 & 3 & 0.748506 & \\
Total & 179.5500 & 11 & & \\
\hline
\end{tabular}

$\mathrm{F}_{0.95 ; 2 ; 9}=4.26 ; \mathrm{F}_{0.95 ; 6 ; 3}=8.94 ; \mathrm{R}^{2}=0.95565$.

TABLE 4. Analysis of variance (ANOVA) of the total phenolic content of the 14-4 genotype murtilla fruit extracts

\begin{tabular}{lcccc}
\hline Source & Sum of squares & df & Mean square & $\boldsymbol{F}$ value \\
\hline Model & 565.3251 & 2 & 282.6625 & 43.98831 \\
Residual & 57.8327 & 9 & 6.425855 & 2.14063 \\
Lack of fit & 46.8821 & 6 & 7.813691 & \\
Pure error & 10.9505 & 3 & 3.650183 & \\
Total & 623.1578 & 11 & & \\
\hline
\end{tabular}

$\mathrm{F}_{0.95 ; 2 ; 9}=4.26 ; \mathrm{F}_{0.95 ; 6 ; 3}=8.94 ; \mathrm{R}^{2}=0.90719$.

(a)



(b)

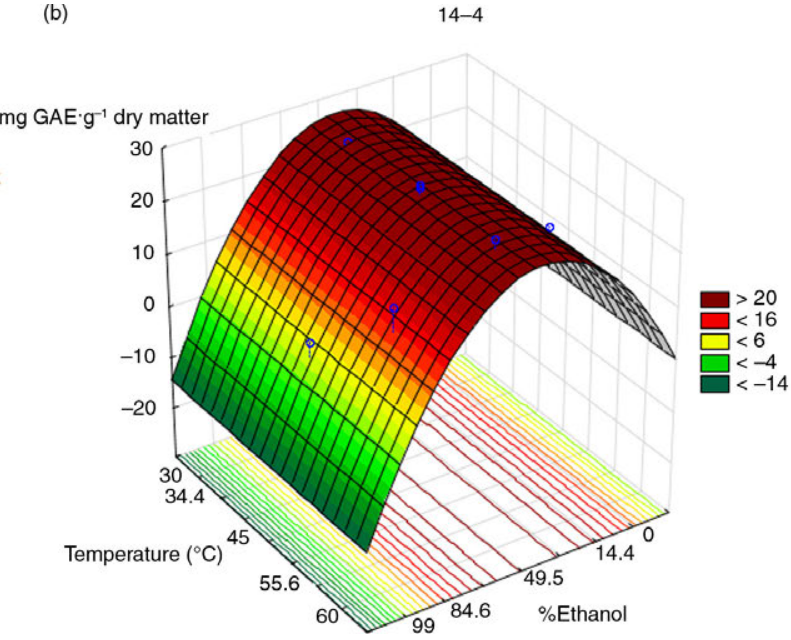

FIGURE 1. Effect of temperature and solvent concentration on the total phenolic content of the wild and 14-4 genotype murtilla fruit extracts.

higher than that of the wild murtilla fruit extract. This outcome is consistent with the concentration reported by Tsao et al. (2003), who found differences in the phenolic content of a cultivated variety of Canadian strawberries and the wild fresh fruit using the same extraction solvent.

Boeing et al. (2014) evaluated the effect of different solvents and their combinations on the extraction of antioxidant compounds from black mulberries (Morus nigra), blackberries (Rubus ulmifolius) and strawberries (Fragaria x ananassa), and they determined the total phenolic content, anthocyanin content and antioxidant capacity. For all of the berries, the acetone/water solvent mixture (70-30\%, $\mathrm{v} / \mathrm{v})$ presented the optimal phenolic compound extraction capacity, whereas for black mulberries, the ethanol/water solvent mixture $(50 / 50$, v/v) presented the highest antioxidant capacity.

Radojković et al. (2013) evaluated the influence of solvent composition (ethanol/water, 40-80\%, $\mathrm{v} / \mathrm{v})$, temperature $\left(40-80^{\circ} \mathrm{C}\right.$ ) and time (20-60 min) on the extraction yield of phenolic compounds, flavonoids, and saccharides and the antioxidant activity of black mulberries (Morus nigra L.). These authors observed that the optimal conditions within the experimental range of the studied variables were as follows: solvent composition of $58.7 \%$, temperature of $58.1^{\circ} \mathrm{C}$ and extraction time of $46.9 \mathrm{~min}$.

According to the results of this study, the optimal conditions for obtaining extracts with a higher total phenolic content was the same for the wild and 14-4 genotype fruits under $49.5 \%$ ethanol 
at $30^{\circ} \mathrm{C}$. Because temperature did not have a significant influence on the amount of total phenolic compounds, a lower temperature was selected to save energy. Therefore, all of the subsequent analyses were performed using extracts produced under optimized conditions $\left(49.5 \%\right.$ and $\left.30{ }^{\circ} \mathrm{C}\right)$ for both samples. Certain components, such as quercetin, epicatechin, and gallic, benzoic and hydrocaffeic acids, were identified by a CG/MS analysis in a previous study (Augusto et al., 2014).

\subsection{Accelerated stability of soybean oil in the Schaal Oven Test}

\subsubsection{Peroxide value and ultraviolet absorption}

The total phenol content determined by the Folin-Ciocalteu method was used to calculate the concentrations of the extracts, which were then added to soybean oil. The total phenolic content was 14.30 and $26.39 \mathrm{mg} \mathrm{GAE} \cdot \mathrm{g}^{-1}$ dry matter for the wild and 14-4 genotype murtilla fruit, respectively.

In Table 5 presents the results of the peroxide analysis, which showed that in all treatments, a gradual increase in peroxide value occurred over time. The TBHQ treatment showed the lowest peroxide values, which was expected because of the stability of TBHQ at higher temperatures.

For the wild and 14-4 genotype murtilla fruit extracts, all of the treatments initially showed the same value $\left(0.20 \pm 0.00\right.$ meq $\mathrm{O}_{2} \cdot \mathrm{kg}^{-1}$ oil). When the wild murtilla fruit extract was applied to soybean oil, the $150 \mathrm{mg} \cdot \mathrm{kg}^{-1}$ treatment showed the lowest peroxide values $\left(2.01 \pm 0.00 \mathrm{meq} \mathrm{O}_{2} \cdot \mathrm{kg}^{-1}\right.$ oil $)$ after 96 hours, and the value was statistically similar to the TBHQ treatment $\left(2.01 \pm 0.00 \mathrm{meq} \mathrm{O}_{2} \cdot \mathrm{kg}^{-1}\right.$ oil). For the $200 \mathrm{mg} \cdot \mathrm{kg}^{-1}$ treatment at 96 hours and the $150 \mathrm{mg} \cdot \mathrm{kg}^{-1}$ treatment at 72 hours, the peroxide values $\left(13.09 \pm 1.01 \mathrm{meq} \mathrm{O}_{2} \cdot \mathrm{kg}^{-1}\right.$ oil and $9.07 \pm 1.01$ meq $\mathrm{O}_{2} \cdot \mathrm{kg}^{-1}$ oil, respectively) were higher compared with the other treatments, which was likely caused by a pro-oxidant effect of the antioxidant compounds on the extract. According to Fukumoto and Mazza (2000), Carocho and Ferrera (2013) and Lee et al. (2016) the pro-oxidant effect can occurs when some antioxidant compounds are added in lipid systems. The protective effects of the wild murtilla fruit extracts were TBHQ $=150 \mathrm{mg} \cdot \mathrm{kg}^{-1}>100 \mathrm{mg} \cdot \mathrm{kg}^{-1}>$ control $>50 \mathrm{mg} \cdot \mathrm{kg}^{-1}>200 \mathrm{mg} \cdot \mathrm{kg}^{-1}$.

For the 14-4 genotype murtilla fruit extract (Table 5), the $200 \mathrm{mg} \cdot \mathrm{kg}^{-1}$ treatment after 96 hours and TBHQ $\left(2.01 \pm 0.00 \mathrm{meq} \mathrm{O}_{2} \cdot \mathrm{kg}^{-1}\right.$ oil $)$ showed the lowest peroxide values. The protective effects of the 14-4 genotype murtilla fruit were TBHQ = $200 \mathrm{mg} \cdot \mathrm{kg}^{-1}>100 \mathrm{mg} \cdot \mathrm{kg}^{-1}=150 \mathrm{mg} \cdot \mathrm{kg}^{-1}>$ control $>50 \mathrm{mg} \cdot \mathrm{kg}^{-1}$.

Luzia and Jorge (2009) analyzed the antioxidant activity of lemon (Citrus limon) seed extract added to soybean oil, which was then subjected to thermal oxidation. The treatments were incubated at $80^{\circ} \mathrm{C}$ for 20 hours, and the samples were collected at various time intervals. After 5 hours, the authors observed peroxide values of approximately $2.75 \mathrm{meq} \mathrm{O}_{2} \cdot \mathrm{kg}^{-1}$ oil for the lemon extract and $3.92 \mathrm{meq} \mathrm{O}{ }_{2} \cdot \mathrm{kg}^{-1}$ oil for TBHQ. The effect of the murtilla fruit extracts cannot be directly compared with that of the lemon extract because of differences in the temperature and time intervals applied for the Schaal Oven Test. However, the lemon seed extract peroxide value was similar to the value obtained for the murtilla extracts at 36 hours (Table 5), which shows the protective effect of the murtilla natural antioxidants. Asha et al. (2015) evaluated the antioxidant activities of butylated hydroxyanisole (BHA) and orange peel powder extract in ghee that was stored at three different temperatures for 21 days, and they observed that the ghee incorporated with orange peel extract showed reduced peroxide values compared with the ghee incorporated with $\mathrm{BHA}$ and the control ghee.

Table 6 shows that the control and $50 \mathrm{mg} \cdot \mathrm{kg}^{-1}$ treatments had the highest values after 96 hours $\left(13.19 \pm 0.17\right.$ and $9.26 \pm 0.73 \mathrm{E}_{1 \mathrm{~cm}}^{1 \%}$, respectively) for both murtilla extracts. For the wild murtilla fruit, the absorption values in all treatments increased,

TABLE 5. Peroxide values (meq $\mathrm{O}_{2} \cdot \mathrm{kg}^{-1}$ oil) of soybean oil added to the wild and 14-4 genotype murtilla fruit extracts obtained via the Schaal Oven Test

\begin{tabular}{|c|c|c|c|c|c|c|c|}
\hline & Time (h) & Control & $50 \mathrm{mg} \cdot \mathrm{kg}^{-1}$ & $100 \mathrm{mg} \cdot \mathrm{kg}^{-1}$ & $150 \mathrm{mg} \cdot \mathrm{kg}^{-1}$ & $200 \mathrm{mg} \cdot \mathrm{kg}^{-1}$ & TBHQ \\
\hline \multirow{4}{*}{$\begin{array}{l}\text { Wild } \\
\text { murtilla } \\
\text { extracts* }\end{array}$} & $\mathbf{0}$ & $0.20 \pm 0.00 \mathrm{~B}$ & $0.20 \pm 0.00 \mathrm{D}$ & $0.20 \pm 0.00 \mathrm{C}$ & $0.20 \pm 0.00 \mathrm{C}$ & $0.20 \pm 0.00 \mathrm{C}$ & $0.20 \pm 0.00 \mathrm{~B}$ \\
\hline & 36 & $0.60 \pm 0.00 \mathrm{Bc}$ & $6.03 \pm 0.00 \mathrm{Ba}$ & $2.01 \pm 0.00 \mathrm{Bb}$ & $2.01 \pm 0.00 \mathrm{Bb}$ & $1.51 \pm 0.50 \mathrm{Cb}$ & $0.20 \pm 0.00 \mathrm{Bc}$ \\
\hline & 72 & $6.09 \pm 1.05 \mathrm{Ab}$ & $4.02 \pm 0.00 \mathrm{Cc}$ & $4.02 \pm 0.00 \mathrm{Ac}$ & $9.07 \pm 1.01 \mathrm{Aa}$ & $4.03 \pm 0.00 \mathrm{Bc}$ & $0.20 \pm 0.00 \mathrm{Bd}$ \\
\hline & 96 & $6.21 \pm 0.05 \mathrm{Ac}$ & $9.32 \pm 0.25 \mathrm{Ab}$ & $5.04 \pm 1.01 \mathrm{Ac}$ & $2.01 \pm 0.00 \mathrm{Bd}$ & $13.09 \pm 1.01 \mathrm{Aa}$ & $2.01 \pm 0.00 \mathrm{Ad}$ \\
\hline \multirow{4}{*}{$\begin{array}{l}\text { 14-4 } \\
\text { Genotype } \\
\text { murtilla } \\
\text { extracts* }\end{array}$} & $\mathbf{0}$ & $0.20 \pm 0.00 \mathrm{~B}$ & $0.20 \pm 0.00 \mathrm{C}$ & $0.20 \pm 0.00 \mathrm{~B}$ & $0.20 \pm 0.00 \mathrm{C}$ & $0.20 \pm 0.00 \mathrm{C}$ & $0.20 \pm 0.00 \mathrm{~B}$ \\
\hline & 36 & $0.60 \pm 0.00 \mathrm{Bcd}$ & $1.51 \pm 0.50 \mathrm{BCbc}$ & $3.02 \pm 1.01 \mathrm{Aa}$ & $2.01 \pm 0.00 \mathrm{BCab}$ & $2.01 \pm 1.16 \mathrm{Bab}$ & $0.20 \pm 0.00 \mathrm{Bd}$ \\
\hline & 72 & $6.09 \pm 1.05 \mathrm{Aa}$ & $2.01 \pm 0.00 \mathrm{Bcd}$ & $1.34 \pm 0.58 \mathrm{Bcd}$ & $3.05 \pm 0.99 \mathrm{Bcb}$ & $5.03 \pm 1.01 \mathrm{Aab}$ & $0.20 \pm 0.00 \mathrm{Bd}$ \\
\hline & 96 & $6.21 \pm 0.05 \mathrm{Ab}$ & $9.07 \pm 1.01 \mathrm{Aa}$ & $4.28 \pm 0.25 \mathrm{Ac}$ & $5.03 \pm 1.01 \mathrm{Abc}$ & $2.01 \pm 0.00 \mathrm{Bd}$ & $2.01 \pm 0.00 \mathrm{Ad}$ \\
\hline
\end{tabular}

*Results expressed as the mean \pm standard deviation. Capital letters in the columns or lower case letters in the rows indicate that the values were not significantly different according to Tukey's test at $5 \%$ probability. 
although the 150 and $200 \mathrm{mg} \cdot \mathrm{kg}^{-1}$ treatments and the TBHQ treatment showed similar values after 96 hours $\left(5.60 \pm 0.37 \mathrm{E}_{1 \mathrm{~cm}}^{1 \%}, 5.61 \pm 0.28 \mathrm{E}_{1 \mathrm{~cm}}^{1 \%}\right.$ and $4.32 \pm 0.2 \mathrm{E}^{1 \%} 1 \mathrm{~cm}$, respectively). The protective effects of the wild murtilla fruit extracts were TBHQ $>150 \mathrm{mg} \cdot \mathrm{kg}^{-1}=200 \mathrm{mg} \cdot \mathrm{kg}^{-1}>100 \mathrm{mg} \cdot \mathrm{kg}^{-1}$ $>50 \mathrm{mg} \cdot \mathrm{kg}^{-1}>$ control. For the 14-4 genotype murtilla fruit, three treatments showed an increase in the absorption values after 96 hours. However, the $150 \mathrm{mg} \cdot \mathrm{kg}^{-1}\left(5.18 \pm 0.01 \mathrm{E}^{1 \%}{ }_{1 \mathrm{~cm}}\right)$ treatment did not exhibit this behavior, and its absorption value was not significantly different from the initial value $\left(4.63 \pm 0.13 \mathrm{E}^{1 \%}{ }_{1 \mathrm{~cm}}\right.$ at 0 hour) and the TBHQ value at 96 hours $\left(4.32 \pm 0.20 \mathrm{E}^{1 \%} \mathrm{~cm}\right)$. Therefore, the protective effects of the 14-4 genotype extracts were $\mathrm{TBHQ}=150 \mathrm{mg} \cdot \mathrm{kg}^{-1}>100 \mathrm{mg} \cdot \mathrm{kg}^{-1}>50 \mathrm{mg} \cdot \mathrm{kg}^{-1}$ $>200 \mathrm{mg} \cdot \mathrm{kg}^{-1}=$ control.

Anwar et al. (2010) estimated the antioxidant activity of methanolic extracts from three varieties of barley in sunflower oil at $60{ }^{\circ} \mathrm{C}$, and after 10 days, the results varied from $8.38 \pm 0.37$ to $9.97 \pm 0.83 \mathrm{E}^{1 \%} 1 \mathrm{~cm}$. These values were higher values than the values found in this study.

\subsubsection{Sensory analysis}

To complete the analysis, the total phenolic content determined via the Folin-Ciocalteu method was used to calculate the concentrations of extracts added to soybean oil. The total phenolic contents were 11.61 and $23.96 \mathrm{mg} \mathrm{GAE} \cdot \mathrm{g}^{-1}$ dry fruit for the wild and $14-4$ genotype murtilla fruit extracts, respectively.

Table 7 shows that only the oxidized control treatment had a higher score for rancid odor at baseline, whereas significant differences were not observed for the other treatments. Therefore, the addition of murtilla fruit extracts (wild and 14-4 genotype at 150 or $200 \mathrm{mg} \cdot \mathrm{kg}^{-1}$ ) did not cause noticeable changes in the soybean oil odor compared with the pure condition (unoxidized control) or the addition of TBHQ, which is a common synthetic antioxidant used by the food industry. After 96 hours, all of treatments showed a higher rancid odor and all of the scores increased except for that of the unoxidized control. At 72 and 96 hours, the TBHQ treatment presented rancid odor scores that were lower than the samples treated with the murtilla fruit extracts. This outcome was expected because this synthetic antioxidant provides good protection at higher temperatures.

Ramsaha et al. (2015) analyzed the antioxidant potential of traditional plants of Mauritius, such as $P$. betle L. (Piperaceae), M. koenigii L. Sprengel (Rutaceae), O. gratissimum L. (Lamiaceae), $O$. tenuiflorum L. (Lamiaceae), and commercially available Mauritian green and black teas. The extracts of these plants were added to sunflower oil, and an odor evaluation was performed using a sensory panel. The results showed that the plant extracts and green tea effectively delayed the development of rancid odors in sunflower oil $(\mathrm{p}<0.05)$.

TABLE 6. Absorption values from the UV absorption analysis at $232 \mathrm{~nm}$ for the wild (a) and 14-4 genotype (b) murtilla fruit extracts added to soybean oil and then subjected to the Schaal Oven Test

\begin{tabular}{|c|c|c|c|c|c|c|c|}
\hline & Time (h) & Control & $50 \mathrm{mg} \cdot \mathrm{kg}^{-1}$ & $100 \mathrm{mg} \cdot \mathrm{kg}^{-1}$ & $150 \mathrm{mg} \cdot \mathrm{kg}^{-1}$ & $200 \mathrm{mg} \cdot \mathrm{kg}^{-1}$ & TBHQ \\
\hline \multirow{4}{*}{$\begin{array}{l}\text { Wild } \\
\text { murtilla } \\
\text { extracts* }\end{array}$} & $\mathbf{0}$ & $4.63 \pm 0.13 \mathrm{C}$ & $4.63 \pm 0.13 \mathrm{C}$ & $4.63 \pm 0.13 \mathrm{C}$ & $4.63 \pm 0.13 \mathrm{~B}$ & $4.63 \pm 0.13 \mathrm{~B}$ & $4.63 \pm 0.13 \mathrm{~A}$ \\
\hline & 36 & $3.60 \pm 0.25 \mathrm{Dc}$ & $4.84 \pm 0.13 \mathrm{BCabc}$ & $5.90 \pm 0.73 \mathrm{Ba}$ & $5.09 \pm 0.10 \mathrm{ABab}$ & $5.25 \pm 0.48 \mathrm{ABab}$ & $4.29 \pm 0.09 \mathrm{Bbc}$ \\
\hline & 72 & $10.70 \pm 0.11 \mathrm{Ba}$ & $6.18 \pm 0.37 \mathrm{Bb}$ & $5.61 \pm 0.24 \mathrm{BCb}$ & $4.83 \pm 0.12 \mathrm{Bc}$ & $4.82 \pm 0.42 \mathrm{ABc}$ & $4.31 \pm 0.05 \mathrm{AB}$ \\
\hline & 96 & $13.19 \pm 0.17 \mathrm{Aa}$ & $9.21 \pm 0.66 \mathrm{Ab}$ & $7.86 \pm 0.52 \mathrm{Ac}$ & $5.60 \pm 0.37 \mathrm{Ad}$ & $5.61 \pm 0.28 \mathrm{Ad}$ & $4.32 \pm 0.20 \mathrm{ABe}$ \\
\hline \multirow{4}{*}{$\begin{array}{l}\text { 14-4 } \\
\text { Genotype } \\
\text { murtilla } \\
\text { extracts* }\end{array}$} & $\mathbf{0}$ & $4.63 \pm 0.13 \mathrm{D}$ & $4.63 \pm 0.13 \mathrm{~B}$ & $4.63 \pm 0.13 \mathrm{C}$ & $4.63 \pm 0.13 \mathrm{BC}$ & $4.63 \pm 0.13 C$ & $4.63 \pm 0.13 \mathrm{~A}$ \\
\hline & 36 & $3.60 \pm 0.25 \mathrm{Cd}$ & $4.84 \pm 0.26 \mathrm{Bbc}$ & $5.68 \pm 0.07 \mathrm{Ba}$ & $4.49 \pm 0.43 \mathrm{Cc}$ & $5.18 \pm 0.10 \mathrm{Bab}$ & $4.29 \pm 0.09 \mathrm{Bc}$ \\
\hline & 72 & $10.70 \pm 0.11 \mathrm{Ba}$ & $5.27 \pm 0.36 \mathrm{Bc}$ & $5.27 \pm 0.05 \mathrm{Bc}$ & $7.26 \pm 0.23 \mathrm{Ab}$ & $5.00 \pm 0.15 \mathrm{BCc}$ & $4.31 \pm 0.05 \mathrm{ABd}$ \\
\hline & 96 & $13.19 \pm 0.17 \mathrm{Aa}$ & $9.26 \pm 0.73 \mathrm{Ab}$ & $6.81 \pm 0.38 \mathrm{Ac}$ & $5.18 \pm 0.01 \mathrm{Bd}$ & $12.72 \pm 0.26 \mathrm{Aa}$ & $4.32 \pm 0.20 \mathrm{ABd}$ \\
\hline
\end{tabular}

*Results expressed as the mean \pm standard deviation. Capital letters in the columns or lower case letters in the rows indicate that the values were not significantly different according to Tukey's test at $5 \%$ probability.

TABLE 7. Rancid odor score from the sensory analysis of the wild and 14-4 genotype murtilla fruit extracts added to soybean oil

\begin{tabular}{|c|c|c|c|c|c|c|c|}
\hline \multirow[b]{2}{*}{ Time (h) } & \multicolumn{7}{|c|}{ Treatments* } \\
\hline & $\begin{array}{l}\text { Unoxidized } \\
\text { control }\end{array}$ & $\begin{array}{l}\text { Oxidized } \\
\text { control }\end{array}$ & Wild $150 \mathrm{mg} \cdot \mathrm{kg}^{-1}$ & $14-4150 \mathrm{mg} \cdot \mathrm{kg}^{-1}$ & Wild $200 \mathrm{mg} \cdot \mathrm{kg}^{-1}$ & $14-4200 \mathrm{mg} \cdot \mathrm{kg}^{-1}$ & TBHQ \\
\hline $\mathbf{0}$ & $1.89 \pm 0.29 \mathrm{Ab}$ & $2.97 \pm 0.35 \mathrm{Ba}$ & $1.83 \pm 0.53 \mathrm{Bb}$ & $1.84 \pm 0.49 \mathrm{Cb}$ & $1.89 \pm 0.64 \mathrm{Cb}$ & $2.10 \pm 0.37 \mathrm{Cb}$ & $1.88 \pm 0.21 \mathrm{Bb}$ \\
\hline 72 & $1.70 \pm 0.28 \mathrm{Ad}$ & $2.68 \pm 0.07 \mathrm{Ca}$ & $2.19 \pm 0.29 \mathrm{Bb}$ & $2.63 \pm 0.29 \mathrm{Ba}$ & $2.46 \pm 0.16 \mathrm{Bab}$ & $2.71 \pm 0.34 \mathrm{Ba}$ & $1.77 \pm 0.30 \mathrm{Bcd}$ \\
\hline 96 & $1.67 \pm 0.22 \mathrm{Ac}$ & $3.80 \pm 0.34 \mathrm{Aa}$ & $3.60 \pm 0.39 \mathrm{Aa}$ & $3.67 \pm 0.35 \mathrm{Aa}$ & $3.61 \pm 0.40 \mathrm{Aa}$ & $3.81 \pm 0.25 \mathrm{Aa}$ & $2.53 \pm 0.15 \mathrm{Ab}$ \\
\hline
\end{tabular}

*Results expressed as the mean \pm standard deviation. Capital letters in the columns or lower case letters in the rows indicate that the values were not significantly different according to Tukey's test at $5 \%$ probability. 
In our study, the TBHQ antioxidant had a better overall effect with respect to the release of odors from soybean oil compared with the murtilla fruit extract treatments.

\section{CONCLUSIONS}

The Response Surface Methodology was able to define the best extraction conditions for obtaining murtilla fruit extracts with a higher total phenolic content in an aqueous alcoholic solution with similar proportions ( $49.5 \%$ ethanol) and at a lower temperature $\left(30^{\circ} \mathrm{C}\right)$.

When added to soybean oil, the murtilla fruit extracts demonstrated good protective activity compared with other natural antioxidants reported in the literature. Although the protective level of the synthetic antioxidant TBHQ was not achieved, the hydro-alcoholic extracts of wild and 14-4 genotype murtilla fruit may be considered a natural source of antioxidants for addition to lipid foods. Additional studies are required to assess the most effective concentrations of these extracts against oxidation reactions.

\section{ACKNOWLEDGMENTS}

The authors are grateful for the support provided by the Project FONDEF AF10I1007 from CONICYT (Chile) and UFRO/FAPESP (Grant $\mathrm{N}^{\circ}$ 2014/50235-7) and the scholarship granted by CAPES (Brazil).

\section{REFERENCES}

Alfaro S, Mutis A, Palma R, Quiroz A, Seguel I, Scheuermann E. 2013. Influence of genotype and harvest year on polyphenol content and antioxidant activity in murtilla (Ugni molinae Turcz) fruit. J. Soil Sci. Plant Nutr. 13, 67-78 https://doi.org/10.4067/s0718-95162013005000007

Alves M, Esteves E, Quintas C. 2015. Effect of preservatives and acidifying agents on the shelf life of packed cracked green table olives from Macanilha cultivar. Food Packaging Shelf Life 5, 32-40. http://dx.doi.org/10.1016/j. fps1.2015.05.001

American Oil Chemists' Society. 2009. Official Methods and Recommended Practices of the American Oil Chemists Society, sixth ed. AOCS Press, Champaign, IL

Anwar F, Abdul Qayyum HM, Ijaz Hussain A, Iqbal S. 2010. Antioxidant activity of $100 \%$ and $80 \%$ methanol extracts from barley seeds (Hordeum vulgare L.): stabilization of sunflower oil. Grasas Aceites 61, 237-243. http://dx.doi. org/10.3989/gya.087409

Asha A, Manjunatha M, Rekha RM, Surendranath B, Heartwin P, Rao J, Magdaline E, Sinha C. 2015. Antioxidant activities of orange peel extract in ghee (butter oil) stored at different storage temperatures. J. Food Sci. Technol. 52, 8220-8227. http://dx.doi.org/10.1007/s13197-015-1911-3

T.R. Augusto-Obara, Scheuermann E, Alencar SM, D'Arce MABR, de Camargo ACd, Vieira TMFdS. 2014. Phenolic compounds and antioxidant activity of hydroalcoholic extracts of wild and cultivated murtilla (Ugni molinae Turcz.). Food Sci. Technol. 34, 667-673. http://dx.doi. org/10.1590/1678-457X.6393

Bektas N, Arslan R, Goger F, Kirimer N, Ozturk Y. 2012. Investigation for anti-inflammatory and anti-thrombotic activities of methanol extract of Capparis ovata buds and fruits. J. Ethnopharmacol. 142, 48-52. http://dx.doi. org/10.1016/j.jep.2012.04.011

Boeing JS, Barizão, EO, Silva BC, Montanher PF, Almeida VC, Visentainer JV. (2014). Evaluation of solvent effect on the extraction of phenolic compounds and antioxidant capacities from the berries: application of principal component analysis. Chem. Cent. J. 8, 1-9. http://dx.doi.org/10.1186/ s13065-014-0048-1

Brewer MS. 2011. Natural antioxidants: sources, compounds, mechanisms of action, and potential applications. Compr. Rev. Food Sci. Food Saf. 10, 221-247. http://dx.doi. org/10.1111/j.1541-4337.2011.00156.x

Carocho M, Ferreira ICFR. 2013. A review on antioxidants, prooxidants and related controversy: Natural and synthetic compounds, screening and analysis methodologies and futures perspectives. Food Chem. Toxicol. 51, 15-25. http://dx.doi.org/10.1016/j.fet.2012.09.021

Cichello SA. 2015. Oxygen absorbers in food preservation: a review. J. Food Sci. Technol. 52, 1889-1895. http://dx.doi. org/10.1007/s13197-014-1265-2

Claro C, Ogalla E, Rodriguez-Rodriguez R, Herrera MD, Alvarez de Sotomayor M. 2015. Phenolic content of extra virgin olive oil is essential to restore endothelial dysfunction but not to prevent vascular inflammation in atherosclerotic lesions of apo E deficient mice. J. Funct. Foods. 15, 126-136. http://dx.doi.org/10.1016/j.jff.2015.03.008

Del Monte D, De Martino L, Marandino A, Fratianni F, Nazzaro F, De Feo V. 2015. Phenolic content, antimicrobial and antioxidant activities of Hypericum perfoliatum $\mathrm{L}$. Ind. Crops Prod. 74, 342-347. http://dx.doi.org/10.1016/j. indcrop.2015.04.036

Fukumoto, LR, Mazza, G. 2000. Assessing antioxidant and prooxidant activities of phenolic compounds. J. Agric. Food Chem. 48, 3597-3604. http://dx.doi.org/10.1021/jf000220w

Institute of Food Technologists. 1981. Sensory evaluation guide for testing food and beverage products. Food Technol. 11, 50-59.

Junqueira-Gonçalves MP, Yáñez L, Morales C, Navarro M, Contreras RA, Zúñiga GE. 2015. Isolation and characterization of phenolic compounds and anthocyanins from murta (Ugni molinae Turcz.) fruits. Assessment of antioxidant and antibacterial activity. Molecules 20, 5698-5713. http://dx.doi.org/10.3390/molecules20045698

Jofré I, Pezoa C, Cuevas M, Scheuermann E, Freires I, Rosalen P, Alencar SM, Romero F. 2016. Antioxidant and vasodilator activity of Ugni molinae Turcz (Murtilla), and its modulatory mechanism in hypotensive response. Oxid. Med. Cell Longev. In press.

Karpińska M, Borowski J, Danowska-Oziewicz M. 2001. The use of natural antioxidants in ready-to-serve food. Food Chem. 72, 5-9. http://dx.doi.org/10.1016/S0308-8146(00)00171-0

Lee C, Gim SY, Kim M-J, Lee J. 2016. Effects of quercetin or rutin on the oxidative stability of stripped or non-stripped soybean oils containing $\alpha$-tocopherol. Eur. J. Lipid Sci. Technol. http://dx.doi.org/10.1002/ejlt.201600329

Luzia DMM, Jorge N. 2009. Antioxidant activity of lemon (citrus limon) seeds extract with addition of soybean oil under thermoxidation process. Rev. Inst. Adolfo Lutz. 68, 58-63.

Radojković M, Zeković Z, Sudar R, Jokić S, Cvetanović A. 2013. Optimization of solid-liquid extraction of antioxidants and saccharides from black mulberry fruit by response surface methodology. J. Food Nutr. Res. 52, 146-155.

Ramsaha S, Aumjaud BE, Neergheen-Bhujun VS, Bahorun T. 2015. Polyphenolic rich traditional plants and teas improve lipid stability in food test systems. J. Food Sci. Technol. 52, 773-782. https://doi.org/10.1007/s13197-013-1060-5

Ribeiro SMR, Barbosa LCA, Queiroz JH, Knödler M, Schieber A. 2008. Phenolic compounds and antioxidant capacity of Brazilian mango (Mangifera indica L.) varieties. Food Chem. 110, 620-626. https://doi.org/10.1016/j.foodchem.2008.02.067

Rodríguez K, Ah-Hen K, Vega-Gálvez A, López J, QuispeFuentes I, Lemus-Mondaca R, Gálvez-Ranilla L. 2014. Changes in bioactive compounds and antioxidant activity during convective drying of murta (Ugni molinae T.) berries. Int. J. Food Sci. Technol. 49, 990-1000. http://dx.doi. org/10.1111/ijfs. 12392 
Scheuermann E, Cea M, Schoch S, Ojeda M, Ihl M. 2002. Stability study of edible sunflower oil colored with chlorophyll pigments and with addition of oregano oleoresin (Origanum vulgare L.) during the storage in darkness. Grasas Aceites 53, 289-297.

Shah MA, Bosco SJ, Mir SA. 2014. Plant extracts as natural antioxidants in meat and meat products. Meat Sci. 98, 21-33. http://dx.doi.org/10.1016/j.meatsci.2014.03.020

Shahidi F. 1997. Natural antioxidants: an overview, in Shahidi F (Ed) Natural Antioxidants: Chemistry, Health Effects, and Applications. AOCS Press, Champaign, pp. 1-11.

Shi C, Cui J, Yin X, Luo Y, Zhou Z. 2014. Grape seed and clove bud extracts as natural antioxidants in silver carp (Hypophthalmichthys molitrix) fillets during chilled storage: effect on lipid and protein oxidation. Food Control. 40, 134-139. https://doi.org/10.1016/j.foodcont.2013. 12.001

Simin N, Orcic D, Cetojevic-Simin D, Mimica-Dukic N, Anackov G, Beara I, Mitic-Culafic D, Bozin B. 2013. Phenolic profile, antioxidant, anti-inflammatory and cytotoxic activities of small yellow onion (Allium flavum L. subsp. flavum, Alliaceae). LWT-Food Sci. Technol. 54, 1, 139-146. http://dx.doi.org/10.1016/j.lwt. 2013.05.023

Singleton VL, Orthofer R, Lamuela-Raventós RM. 1999. Analysis of total phenols and other substrates and antioxidants by means of Folin - Ciocalteu reagent. Methods Enzymol. 299, $152-178$.

Stat Soft INC. 2013. Statistica (data analysis software system), version 12. www.statsoft.com.

Suwalsky, M, Avello, M. 2014. Antioxidant capacity of Ugni molinae fruit extract on human erythrocytes: an in vitro study. J. Membr. Biol. 247, 703-712. https://doi. org/10.1007/s00232-014-9692-6

Tsao R, Yang R, Socknovie E, Zhou T, Dale A. 2003. Antioxidant phytochemicals in cultivated and wild Canadian strawberry. International 616, 25-35.

Yanishlieva NV, Marinova E, Pokorný J. 2006. Natural antioxidants from herbs and spices. Eur. J. Lipid Sci. Technol. 108, 776-793. http://dx.doi.org/10.1002/ejlt.200600127

Zhang L, Ravipati AS, Koyyalamudi SR, Jeong SC, Reddy N, Smith PT, Bartlett J, Shanmugam K, Münch G, Wu MJ. 2011. Antioxidant and anti-inflammatory activities of selected medicinal plants containing phenolic and flavonoid compounds. J. Agric. Food Chem. 59, 12361-12367. http://dx.doi.org/10.1021/jf203146e

Zhang Y, Butelli E, De Stefano R, Schoonbeek HJ, Magusin A, Pagliarani C, Wellner N, Hill L, Orzaez D, Granell A, Jones JD, Martin C. 2013. Anthocyanins double the shelf life of tomatoes by delaying overripening and reducing susceptibility to gray mold. Curr. Biol. 23, 1094-1100. http:// dx.doi.org/10.1016/j.cub.2013.04.072 